\title{
PERANAN PEMUDA KARANG TARUNA DALAM \\ MENGIMPLEMENTASIKAN PANCASILA SILA KELIMA DI RT.07 \\ RW.03 DUSUN SEGULUNG, DESA SEGULUNG, KECAMATAN \\ DAGANGAN, KABUPATEN MADIUN TAHUN 2015
}

\section{Toni Susanto*}

\begin{abstract}
Abstrak
$\mathrm{P}$ adakarang taruna terdapat satu program kerja yang ditujukan untuk mewujudkan kesejahteraan sosial masyarakat terutama pada desa atau kelurahan yang di tempati. Hal ini sesuai dengan amalan Pancasila sila kelima yang berbunyi "Keadilan sosial bagi seluruh rakyat Indonesia". Dengan demikian, penelitian ini bertujuan untuk mendeskripsikan makna Pancasila dan karang taruna serta peranan pemuda karang taruna dalam mengimplementaikan pancasila sila kelima. Jenis penelitian yang digunakan adalah penelitian kualitatif.Penelitian ini dilaksanakan di Dusun Segulung, Desa Segulung, Kecamatan Dagangan, Kabupaten Madiun.Sumber data yang digunakan berupa data primer dan sekunder. Teknik pengumpulan data dengan wawancara, observasi dan dokumentasi. Teknik keabsahan data dengan triangulasi teknik.Analisis data melalui reduksi data, penyajian data, dan penarikan simpulan dan verifikasi. Hasil penelitian menunjukkan bahwa makna pancasila sila kelima adalah mengajak masyarakat aktif dalam memberikan sumbangan yang wajar sesuai dengan kemampuan dan kedudukannya demi terwujudnya kesejahteraan umum. Organisasi di masyarakat yang berperan mengajak masyarakat aktif mewujudkan kesejahteraan umum adalah karana taruna. Karang taruna tumbuh dan berkembang atas dasar kesadaran terhadap keadaan dan permasalahan di lingkungannya serta adanya tanggungjawab sosial untuk terus berusaha menanganinya. Peranan pemuda karang taruna dalam mengimplementaikan pancasila sila kelima ada tiga macam kegiatan.Kegiatan yang dilakukan yaitu, sinoman, kerja bakti dan kepanitian hari kemerdekaan dan hari besar keagamaan.
\end{abstract}

\section{Kata Kunci: Makna,Pancasila, Karang Taruna}

\footnotetext{
* Mahasiswa Prodi PPKn IKIP PGRI Madiun
} 
PENDAHULUAN

Pemuda adalah golongan manusia muda yang masih memerlukan pembinaan dan pengembangan ke arah yang lebih baik agar dapat melanjutkan dan mengisi pengembangan yang kini telah berlangsung. Pemuda Indonesia dewasa ini sangat beraneka ragam, terutama apabila dikaitkan dengan kesempatan pendidikan. Keragaman tersebut pada dasarnya tidak mengakibatkan perbedaan dalam pembinaan dan pengembangan generasi muda. Kedudukan pemuda dalam masyarakat adalah sebagai makhluk moral, mahluk sosial. Artinya beretika, bersusila, dijadikan sebagai barometer moral kehidupan bangsa dan pengoreksi. Sebagai Makhluk sosial artinya pemuda tidak dapat berdiri sendiri, hidup bersamasama, dapat menyesuaikan diri dengan norma-norma, kepribadian, dan pandangan hidup yang dianut masyarakat. Sebagai makhluk individual artinya tidak melakukan kebebasan sebebas-bebasnya tetapi disertai rasa tanggung jawab terhadap diri sendiri, terhadap masyarakat, dan terhadap Tuhan Yang maha Esa (Jati, 2012: 7).
Pemuda akan meneruskan cita-cita sebuah bangsa untuk memimpin dan mengatur sebuah negara harus memiliki kepribadian yang baik, kecerdasan yang dilandasi dengan ilmu, wawasan yang luas, memiliki jiwa yang semangat, pikiran terbuka dan tujuan yang baik, dan bermanfaat untuk kemajuan bangsa dan negara. Akan tetapi,pemuda Indonesia pada saat ini telah banyak terjerumus pada dunia modernisasi dan westernisasi sehingga melupakan adat ketimuran yang dimiliki yang dikenal oleh negara lain sebagai negara yang menjunjung tinggi moral dan adat kesopanan. Generasi Indonesia saat ini mengalami krisis identitas dan korban dari gaya hidup hedonisme barat. Semakin banyak life style dari luar Negara Indonesia yang masuk, semakin tidak terkendali generasi muda Indonesia saat ini. Contoh nyata adalah banyak pemuda yang lebih suka cara berpakaian meniru model pakaian dari luar negeri yang terbuka dan kurang sopan.

Peranan pemuda dalam sosialisasi bermasyarakat sungguh menurun drastis, Dulu setiap ada 
kegiatan masyarakat seperti kerja bakti, acara-acara keagamaan, adat istiadat, yang berperan aktif dalam menyukseskan acara tersebut adalah pemuda sekitar.Pemuda sekarang lebih suka dengan kesenangan, selalu bermain-main dan bahkan ketua RT/ RWnya saja tidak tahu. Kini pemuda-pemudi lebih suka berperan di dunia maya daripada dunia nyata. Contohnya, seperti lebih suka aktif di Facebook, Twitter, Path, Instagramdan lain-lain.

Peranan pemuda ada di dalam Undang-Undang Republik Indonesia Nomor 40 Tahun 2009 tentang Kepemudaan yang berbunyi: 1) bahwa dalam sejarah perjuangan bangsa Indonesia sejak perintisan pergerakan kebangsaan Indonesia, pemuda berperan aktif sebagai ujung tombak dalam mengantarkan bangsa dan negara Indonesia yang merdeka, bersatu, dan berdaulat, 2) bahwa dalam pembaruan dan pembangunan bangsa, pemuda mempunyai fungsi dan peran yang sangat strategis sehingga perlu dikembangkan potensi dan perannya melalui penyadaran, pemberdayaan, dan pengembangan, sebagai bagian dari pembangunan nasional, 3) bahwa untuk mewujudkan tujuan pembangunan nasional, diperlukan pemuda yang berakhlak mulia, sehat, tangguh, cerdas, mandiri, dan profesional, 4) bahwa untuk membangun pemuda, diperlukan pelayanan kepemudaan dalam dimensi pembangunan di segala bidang kehidupan bermasyarakat, berbangsa, dan bernegara berdasarkan Pancasila dan UndangUndang Dasar Negara Republik Indonesia Tahun 1945, 5) bahwa berdasarkan pertimbangan sebagaimana dimaksud dalam huruf $a$, huruf $b$, huruf $c$, dan huruf $d$, perlu membentuk Undang-Undang tentang Kepemudaan. Berdasarkan UndangUndang Kepemudaan tersebut, dapat disimpulkan bahwa peranan pemuda dalam membangun bangsa dan bernegara sudah ada dasar hukumnya dengan jelas dan dapat menjadi acuan dan pedoman bagi para pemuda.

Kehidupan bermasyarakat terutama di lingkungan tempat tinggal seseorang pasti adanya satu kelompok organisasi, salah satunya ada kelompok organisasi karang taruna. Dinamika karang taruna di tengah masyarakat yang terjadi 
beberapa tahun terakhir ini sudah sepantasnya mendapatkan respon secara positif sebagai bagian dari proses penguatan peran serta pemuda di bidang kesejahteraan sosial. Karang taruna merupakan organisasi sosial pengembang generasi muda yang berkembang dan tumbuh atas dasar kesadaran sosial dari, oleh, dan untuk masyarakat terutama di wilayah desa/kelurahan dan terutama bergerak dibidang kesejahteraan sosial. Karang taruna bertujuan untuk meningkatkan dan mengembangkan cipta, rasa, karsa dan karya generasi muda dalam mengembangkan sumber daya manusia. Organisasi karang taruna biasanya tumbuh dan berkembang dari generasi muda, dikelola oleh generasi muda dan untuk kepentingan generasi muda dan masyarakat di wilayah desa dan kelurahan atau komunitas adat sederajat. Oleh karena itu, setiap desa atau kelurahan dapat mengembangkan karang tarunanya sendiri.Padakarang taruna terdapat satu program kerja yang ditujukan untuk mewujudkan kesejahteraan sosial masyarakat terutama pada desa atau kelurahan yang di tempati (Pedoman Dasar Karang Taruna
Kementerian Sosial Republik Indonesia, 2013: 12).

Pemuda juga harus berperan aktif dalam bidang organisasi kemasyarakatan salah satunya adalah karang taruna. Karang taruna merupakan tempat para pemuda belajar dan mengembangkan potensi dirinya dalam berorganisasi. Pada karang taruna terdapat juga nilai-nilai luhur Pancasila yang harus dipahami dan diamalkan sebagai dasar dan pedoman hidup. Untuk itu, peranan pemuda karang taruna hendaknya harus selalu memegang teguh dan mengimplementasikan nilai-nilai di setiap sila Pancasila.

Menurut Kaelan (2009: 68), Pancasila adalah hierarkis dan mempunyai bentuk piramidal, diantara satu sila dengan sila yang lainya tidak ada sangkut-pautnya, maka Pancasila itu menjadi terpecahpecah, sehingga tidak dapat dipergunakan sebagai suatu asas kerohanian bagi negara. Oleh karena itu, tiap-tiap sila dapat diartikan dalam bermacam-macam maksud. Pada kehidupan bangsa Indonesia diakui bahwa nilai Pancasila adalah pandangan hidup yang berkembang dalam sosial budaya Indonesia yang 
diyakini sebagai jiwa dan kepribadian bangsa.

Pancasila sebagai dasar falsafah negara Indonesia sebagai berikut: 1) Ketuhanan Yang Maha Esa, 2) Kemanusiaan yang adil dan beradab, 3) Persatuan Indonesia, 4) Kerakyatan yang dipimpin oleh hikmat kebijaksanaan dalam pemusyawaratan perwakilan, 5) Keadilan sosial bagi seluruh rakyat Indonesia. Berdasarkan rumusan keadilan sosial sila-sila Pancasila, sila kelima yaitu "Keadilan sosial bagi seluruh rakyat Indonesia" senantiasa merupakan suatu kesatuan dengan sila-sila yang lainya. Sila kelima merupakan pengkhususan sila-sila yang mendahuluinya. Selain itu, sila kelima didasari dan dijiwai sila-sila yang mendahuluinya, yaitu Ketuhanan Yang Maha Esa, Kemanusiaan yang adil dan beradab, Persatuan Indonesia, Kerakyatan yang dipimpin oleh hikmat kebijaksanaan dalam permusyawaratan/perwakilan. Oleh karena itu, dalam pelaksanaanya sila kelima ini tidak dapat dilaksanakan terpisah dengan sila-sila yang lainnya.
Keadilan sosial dalam Pancasila sila kelima dengan keempat sila yang lainnya senantiasa merupakan suatu kesatuan.Sila kelima dalam hubungannya dengan sila-sila yang lainnya senantiasa saling mengkualifikasi. Oleh karena itu, perumusan persatuan dan kesatuannya adalah keadilan sosial bagi seluruh rakyat Indonesia yang berketuhanan Yang Maha Esa, yang berkemanusiaan yang adil dan beradab, berpersatuan Indonesia, berkerakyatan yang dipimpin oleh hikmat kebijaksanaan dalam permusyawaratan/perwakilan. Jadi sila kelima senantiasa tidak dapat dipisahkan dengan sila-sila yang lainya.

\section{METODE PENELITIAN}

Jenis penelitian yang digunakan adalah penelitian kualitatif. Penelitian ini dilaksanakan di Dusun Segulung, Desa Segulung, Kecamatan Dagangan, Kabupaten Madiun.Sumber data yang digunakan berupa data primer dan sekunder. Data primer diperoleh dari Kepala Dusun, Ketua Karang Taruna, Anggota Karang Taruna, dan Tokoh masyarakat sebanyak 8 informan. 
Data sekunder berupa kata-kata atau tindakan, sumber tertulis, foto dan data statistik yang diperoleh saat penelitian. Teknik pengumpulan data dilakukan dengan teknik wawancara, observasi dan dokumentasi. Teknik keabsahan data dilakukan dengan triangulasi teknik dengan membandingkan wawancara dan observasi serta dokumentasi. Data hasil penelitian dianalisis melalui reduksi data, penyajian data, dan penarikan simpulan dan verifikasi.

\section{HASIL DAN PEMBAHASAN}

1. Makna Pancasila Sila Kelima Pancasila sila kelima berbunyi "Keadilan sosial bagi seluruh rakyat Indonesia". Makna sila ini adalah mengajak masyarakat aktif dalam memberikan sumbangan yang wajar sesuai dengan kemampuan dan kedudukannya demi terwujudnya kesejahteraan umum.Ini dikembangkan dengan perbuatan luhur yang mencerminkan sikap dan suasanan kekeluargaan dan kegotongroyongan. Penjiwaan yang menyatu terhadap sila tersebut pada akhirnya akan menimbulkan rasa sosial di dalam masyarakat contohnya saling membantu dan tolong menolong. Oleh karena itu, di dalam lingkungan masyarakat hendaknya masih menggunakan nilai-nilai sosial dalam melakukan setiap kegiatan karena fungsinya adalah untuk lebih saling mempunyai rasa tolong menolong, gotong-royong dan saling membantu sesama.

2. Makna Karang Taruna

Menurut Kepala Desa Segulung, karang taruna sebagai tempat untuk para pemuda yang ingin belajar berorganisasi dan menggali potensi dirinya di dalam lingkungan masyarakat. Selain itu, untuk belajar hidup berdampingan dengan masyarakat dan ikut serta berpartisipasi aktif dalam setiap kegiatan yang dilakukan oleh masyarakat itu sendiri. Menurut tokoh masyarakat, karang taruna juga sebagai tempat para anak muda melakukan kegiatankegiatan yang didasari semangat dan rasa kebersamaan untuk tujuan membantu dan mengembangkan setiap kegiatan masyarakat. Belajar di dalam 
organisasi pemuda karang taruna memiliki manfaat yang baik untuk para pemuda agar mengetahui dan mengerti cara berorganisasi yang sesuai dengan aturan-aturan yang berlaku.

Menurut anggota karang taruna bahwa karang taruna tumbuh dan berkembang atas dasar kesadaran terhadap keadaan dan permasalahan di lingkungannya serta adanya tanggungjawab sosial untuk terus berusaha menanganinya. Kesadaran dan tanggungjawab sosial tersebut merupakan modal dasar untuk tumbuh dan berkembangnya karang taruna. Terwujudnya pertumbuhan dan perkembangan kesadaran dan tanggungjawab sosial setiap generasi muda dapat memberikan pembinaan dan pemberdayaan kepada generasi muda, agar lebih mengetahui keadaan dan situasi permasalahan sosial yang dihadapi, kebutuhan-kebutuhan yang diperlukan, sumber/potensi yang tersedia agar ada penerus generasi muda yang mampu menggantikan penerus lainnya.
3. Peranan Pemuda Karang Taruna dalam Mengimplementasikan Pancasila Sila Kelima

Karang taruna RT.07/ RW.03 di Dusun Segulung ini beranggotakan 12 laki-laki dan ditambah 3 sampai 4 perempuan.Pada penelitian ini, peranan pemuda karang taruna tersebut dalam mengimplementaikan pancasila sila kelima ada tiga macam kegiatan. Kegiatan yang dilakukan yaitu, sinoman, kerja bakti dan kepanitian hari kemerdekaan dan hari besar keagamaan.

Kegiatan sinoman adalah kegiatan para pemuda yang memiliki tujuan kebersamaan dan gotong-royong membantu masyarakat yang memiliki hajatan. Wujud kegiatan sinoman ini adalah bentuk kegotongroyongan sosial. Tujuannya untuk membina dan meningkatkan kerukukan antarsesama warga. Selain untuk melestarikan budaya yang telah ada secara turun temurun juga untuk membina pemuda dan pemudi dalam rangka meningkatkan sumber daya 
manusia yang lebih baik dalam suasana kekeluargaan dan kegotong-royongan.

Kerja bakti merupakan sarana kebersamaan antarwarga guna membantu tercapainya kenyamanan desa dengan melakukan pembangunan atau kebersihan desa. Kegiatan kerja bakti yang dilakukan oleh karang taruna dilakukan bersama dengan warga lingkungan sekitar RT.07/ RW.03 dan biasanya dilaksanakan sebulan sekali. Kegiatan yang dilakukan adalah membersihkan jalan dari rumput-rumput liar dan membersihkan saluran air agar tidak terjadi banjir pada saat musim penghujan. Selain itu, ikut membantu warga yang sedang membangun rumah (dalam bahasa Jawa dikenal dengan nama sambatan). Hal ini dilakukan sebagai wujud kerukunan dan kebersamaan.

Karang taruna juga memilki fungsi dan peran yang sangat banyak di dalam masyarakat salah satunya adalah sebagai panitia hari kemerdekaan dan hari besar keagamaan. Kegiatan pada saat hari kemerdekaan yang dilakukan biasanya menggelar berbagai macam acara lomba-lomba untuk anak-anak di sekitar lingkungan RT.07/ RW.03 Dusun Segulung. Setelah itu, biasanya diadakan acara pentas seni panggung gembira untuk anak-anak dan remaja pada malam harinya. Hal itu bertujuan untuk lebih memeriahkan hari kemerdekaan dan untuk membuat hiburan bagi anak-anak dan warga sekitar.

Selain hari kemerdekaan, karang taruna juga ikut membantu dalam hari besar keagamaan. Kegiatan yang dilakukan biasanya adalah ikut menjadi panitia dalam penerimaan dan pengeluaran zakat fitrah di masjid. Selain itu, juga ikut menjadi panitia penyembelihan hewan kurban pada saat Idul Adha dan ikut langsung membagikan kepada masyarakat yang membutuhkan.

Karang taruna dapat menciptakan kerukunan karena dengan adanya organisasi tersebut, masyarakat lebih hidup saling gotong royong, tolong menolong antarsesama warga, tidak memandang latar belakang sosial dan kondisi warga untuk 
mendapatkan bantuan. Sebagai pemuda yang memiliki jiwa dan rasa sosial yang tinggi, hendaknya memang lebih mengutamakan kepentingan sosial daripada kepentingan pribadi. Nilai-nilai sosial dapat menumbuhkan rasa saling tolong menolong antar sesama tanpa adanya pamrih atau balas jasa. Keadilan sosial di masyarakat harus ditanamkan dan dilakukan agar tidak terjadi ketimpangan sosial di dalam lingkungan agar masyarakat dapat hidup berdampingan dengan baik dan rukun.

\section{SIMPULAN}

Pancasila sila kelima berbunyi "Keadilan sosial bagi seluruh rakyat Indonesia". Makna sila ini adalah mengajak masyarakat aktif dalam memberikan sumbangan yang wajar sesuai dengan kemampuan dan kedudukannya demi terwujudnya kesejahteraan umum.

Organisasi di masyarakat yang berperan mengajak masyarakat aktif mewujudkan kesejahteraan umum adalah karana taruna. Karang taruna tumbuh dan berkembang atas dasar kesadaran terhadap keadaan dan permasalahan di lingkungannya serta adanya tanggungjawab sosial untuk terus berusaha menanganinya. Peranan pemuda karang taruna dalam mengimplementaikan pancasila sila kelima ada tiga macam kegiatan. Kegiatan yang dilakukan yaitu, sinoman, kerja bakti dan kepanitian hari kemerdekaan dan hari besar keagamaan.

Karang taruna dapat menciptakan kerukunan karena dengan adanya organisasi tersebut, masyarakat lebih hidup saling gotong royong, tolong menolong antarsesama warga, tidak memandang latar belakang sosial dan kondisi warga untuk mendapatkan bantuan. Sebagai pemuda yang memiliki jiwa dan rasa sosial yang tinggi, hendaknya memang lebih mengutamakan kepentingan sosial daripada kepentingan pribadi. Nilainilai sosial dapat menumbuhkan rasa saling tolong menolong antarsesama tanpa adanya pamrih atau balas jasa. Keadilan sosial di masyarakat harus ditanamkan dan dilakukan agar tidak terjadi ketimpangan sosial di dalam lingkungan agar masyarakat dapat hidup berdampingan dengan baik dan rukun. 
DAFTAR PUSTAKA

Dewanto

$\mathrm{N}$.

Jati.2008.

Pemberdayaan \& Peranan Pemuda

(Online),(http://eprints.uny.ac .id/9356/2/bab\%202\%20_NI

M\%2008102241022.pdf, diunduh 1 April 2015).

Djam'an Satori \& Aan Komariah. 2013. Metodologi Penelitian Kualitatif. Bandung: Alfabeta.

H. Suryono. 2005. Pancasila Progresif. Surakarta: Paradigma.

HB.Sutopo. 2002. Metodologi Penelitian Kualitatif. Surakarta: Sebelas Maret University Press.

Kaelan. 2009. Filsafat Pancasila. Yogyakarta: Paradigma.

$\begin{array}{lr}\text { 2012. } & \text { Pendidikan } \\ \text { Kewarganegaraan } & \text { untuk } \\ \text { Perguruan } & \text { Tinggi. } \\ \text { Yogyakarta: } & \text { Universitas } \\ \text { Gajah Mada. } & \end{array}$

Kementrian Sosial Republik Indonesia. 2013. Pedoman Dasar Karang Taruna. Jakarta: Direktur Jendral Pemberdayaan Sosial dan Penanggulangan Kemiskinan.

Lexi J. Moleong. 2012. Metodologi Penelitian Kualitatif. Bandung: PT. Remaja Rosdakarya.

Ludi D. Septian. 2014. Pancasila dan Implementasi Sila Keempat \& Kelima.
(Online),(http://septianludy.bl ogspot.com/2014/07/pancasil a-dan-implementasi-silakeempat.html, diunduh 1 April 2015).

S. Nasution. 2012. Metode Research (Penelitian Ilmiah). Jakarta: Bumi AksaraAlfabeta.

Sugiyono. 2013. Metode Penelitian Kuantitatif Kualitatif dan $R \& D$. Bandung: Alfabeta.

Sugiyono. 2014. Memahami Penelitian Kualitatif. Bandung: CV Alfabeta.

Tim Dosen Pendidikan Pancasila IKIP PGRI MADIUN. 2008. Pendidikan Pancasila Untuk Kalangan Sendiri. Madiun: IKIP PGRI MADIUN.

Tim Permata Press. 2011. UUD 1945. Jakarta: Permata Press.

Undang-Undang Republik Indonesia Nomor 40 Tahun 2009 Tentang Kepemudaan. 